\title{
The Risk Associated to the Lack of Information about Clove Cigarettes
}

\author{
João Marcelo Astolfi Picanço*, Renata Pereira Limberger and Miriam Anders Apel \\ Faculty of Pharmacy, Federal University of Rio Grande do Sul (UFRGS), Brazil \\ *Corresponding author: João Marcelo Astolfi Picanço, Faculty of Pharmacy, Federal University of Rio Grande do Sul (UFRGS), \\ Brazil
}

\begin{abstract}
ARTICLE INFO
Received: 崫 June 03, 2019

Published: 幽 June 12, 2019

Citation: João Marcelo Astolfi Picanço, Renata Pereira Limberger, Miriam Anders - Apel. The Risk Associated to the Lack of Information about Clove Cigarettes. Biomed J Sci \& Tech Res 18(5)2019. BJSTR. MS.ID.003205.
\end{abstract}

Keywords: Clove Cigarettes; Kretek; Toxicological Risks; Regulatory Agencies

\begin{abstract}
Indonesian clove cigarettes, commonly known as "kretek", emerged around the 1880 s, as a blend of tobacco and clove buds (Syzygium aromaticum [L.] Merrill \& Perry) rolled into cornhusks. It is believed that the first use of kretek was related to the relief of chest pain in asthmatic individuals. The current composition consists of tobacco (approximately 60 to 85\%), dried clove buds (about 15 to $40 \%$ ) and some kind of sauce characteristic of each brand, added to give the differential flavor; each region has a preference for different flavors, among them those obtainable with eugenol, menthol, elemycin and coumarin, for example. However, the sauce ingredients are generally kept in absolute secrecy. Due to this milder action, the tobacco products containing eugenol, menthol and similar substances are usually better accepted among the younger population because they reduce the perception of risk associated with smoking, facilitating the first contact with the cigarette. The lack of information about toxicological risks, associated with this apparent harmlessness causes a binged use of the kretek. Despite the growing wave of awareness around the world, the peculiarities of clove cigarettes are not completely understood. The first step in understanding the effects of kretek is the elucidation of the constituent substances, so that toxicological studies can be better targeted at the definition of adverse and harmful effects.
\end{abstract}

\section{Introduction}

Nicotiana tabacum $L$. (Solanaceae), the plant from which most of the commercialized tobacco is extracted, has been grown by the Pre-Columbian American Peoples for more than eight thousand years. Brought to Europe by Christopher Columbus in November 1492 , the use of the substance was popularized in the late $16^{\text {th }}$ century, when the plant was offered as an analgesic for Queen Catherine de Medici by the French ambassador Jean Nicot, whose name was honored when baptizing nicotine, the active ingredient of the plant [1]. The great need of tobacco for the soldiers who fought in World War I had two direct consequences: the establishment of cigarettes as the main form of tobacco consumption-prioritizing mass production of the product, in a standardized assembly line, replacing forms whose preparation would require greater control and the popularization of cigarette consumption as a sophisticated habit [2].

The Hollywood film industry, sponsored by major tobacco companies, was responsible for the association of cigarette with the bohemian, artistic, and nostalgic world - about two-thirds of the 50 top box office movies from the late 1930s to the early 1950s were associated with the major cigarette brands then [3]. The splendor mystified by the great stars of the seventh art concerning the habit of smoking takes its toll by encouraging young adults to initiate smoking. When exposed to tobacco use in films, a dose-response correlation is observed regarding the likelihood of smoking one cigarette or more within 30 days after exposure [4]. According to more recent data from the World Health Organization (WHO) the prevalence of continuous cigarette uses among teenagers aged 13 to 15 years is about $5 \%$; for people older than 15 years, the average number of cigarettes smoked per day is approximately 11 [5]. In these circumstances, smoother forms of introduction to smoking may have conducive consequences for an escalation of this global public health problem.

\section{Kretek}

Indonesian clove cigarettes, commonly known as "kretek" onomatopoeia for the sound of burning leaves - appeared around the 1880s, as a mixture of tobacco and clove buds (Syzygium 
aromaticum [L.] Merrill \& Perry) rolled in a corn husk. It is believed that the first use of kretek has been related to the relief of chest pain in asthmatic individuals, since in Indonesia essential oils of cloves and other plants are used for analgesia - nowadays, the clove cigarettes are inserted in the smoking culture worldwide, as a form of getting high within the law, as a "legal high". At the first moment of establishment of the clove cigarette trade, the distribution was made in the local pharmacies close to the manufacturing sites; however, there is no scientific documentation supporting the pharmacological use of kretek [6,7]. The current composition consists of tobacco (approximately 60 to 85\%) - usually Indonesian, although domestic products may be used depending on where it is prepared - dried clove buds (about 15 to 40\%) and some kind of sauce characteristic of each brand added to give the differential flavor between them $[7,8]$.

The sauce, or "saus" in Indonesian industry, is usually made taking into account the particularities of the place where the brand is marketed; it is known for example that in West Java province, people prefer spicy flavors, which can be obtained through menthol, elemycin and coumarin, for example. However, the seasoning ingredients are usually kept in absolute secrecy - only two to three employees know the exact composition of the kretek, depending on the brand [6]. One of the active ingredients that can be found in large quantities, both in clove leaves and buds, is eugenol, being the main secondary metabolite present in the plant $[9,10]$. It is known that eugenol has an antiseptic, anti-inflammatory and anesthetic action, and such effects have an influence in the consumption of cigarettes. Smoke containing eugenol has a soothing function that causes numbness in the pain receptors in the mouth and throat; this reduces the characteristic roughness of smoking. For this, the kreteks are commonly known as "trainer cigarettes" [7,11,12].

Due to this milder action, the tobacco products containing eugenol, menthol and similar substances are usually better accepted among the younger population because they reduce the perception of risk associated with smoking, facilitating the first contact with the cigarette [13]. Demographic studies on the population using alternative tobacco products demonstrate that young people who have never had prior contact with tobacco are more likely to use alternative tobacco regularly. Tobacco use is made less frequently, and users have fewer dependency symptoms; however, the amount of interactions with alternative tobacco products required to show dependence is significantly lower when compared to ordinary tobacco users, and despite the lower frequency, larger amounts of cigarettes are used by interaction [14].

\section{Regulations}

Worldwide: Regarding laws on the sale and consumption of tobacco products with additives, Canada pioneered. On June 4th, 2009, Bill C-32 was approved by the Canadian Parliament, adding to the Tobacco Act a ban on a list of substances to be added to cigarettes, among them menthol, sauces, herbs and spices [15].
The United States subsequently approved on June $22^{\text {nd }}, 2009$ the Public Law 111- 31, in addition to the Family Smoking Prevention and Tobacco Control Act; despite mentioning the clove specifically as a banned substance, menthol was off the list, leaving its use open for interpretation [16]. Since clove cigarettes make up a large part of Indonesia's GDP, the Javanese government entered in a dispute with the US government in the World Trade Organization, mainly because of the apparent bias regarding menthol. The law has been maintained and the US sales ban continues; however, the online purchase of international manufacturers is not regulated [17].

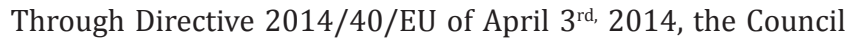
and the European Parliament called on the Member States to prohibit the sale of tobacco products with "characteristic flavor" in which kreteks and menthol cigarettes may be included. Unlike US law, the directive does not apply only to cigarettes; the addition of flavor to electronic cigarettes is at the discretion of each Member State [18]. Australia does not have any law regarding the consumption and sale of tobacco with additives; however, it is important to note that the government of West Australia, the country's largest state, has maintained since April 2006 the Tobacco Products Control Act, which specifically mentions menthol and spices - placing the clove in this category - as permissible substances. This means that, although Canada is a pioneer in the restriction of substances, Australia has stepped up on legislations of any kind about kretek [19].

Brazil: Through the Resolution of the Collegiate Board of Directors (RDC No. 14) of March 15 ${ }^{\text {th }}, 2012$, the maximum limits for tar, nicotine and carbon monoxide in the primary smoke of tobacco products were established by the National Health Surveillance Agency (ANVISA). In addition, the amendment also prohibits any type of additives, including sugars, sweeteners and flavorings, except for additives that are strictly used to recompose the original contents of tobacco leaves [20]. However, the National Confederation of Industries (CNI) filed a Direct Action of Unconstitutionality (ADI No. 4874) requesting the repeal of the paragraphs of the resolution concerning the use of additives, alleging that there is no evidence that these substances are harmful to health, reinforcing that ANVISA's regulatory competence only concerns substances that present a proven health risk [21]. The injunction was accepted on September $13^{\text {th }}, 2013$, suspending regulation until the Plenary's judgment [22]. In February 2018, the ADI was judged by the STF ministers and, by 6 votes to 5 , the suspense injunction was overturned. After the publication of the Reclamation No. 32787 in December 2018, RDC No. 14/2012 became valid in national territory; however, taking into account that the decision does not have a binding effect, it opens a loophole so that the tobacco industry can take action in other spheres of public power, such as state courts [23].

\section{Conclusion}

Despite the growing wave of awareness around the world, the peculiarities of clove cigarettes are not completely understood. Due 
to its softer content, smooth taste and sophisticated appearance, kretek has great appeal among younger populations whose critical thinking is not fully formed yet. Similar to the popularization of marijuana, the lack of knowledge of the content and effect of clove cigarettes opens a gap for the presumption of harmlessness. The first step in understanding the effects of kretek is the elucidation of the constituent substances, so that toxicological studies can be better targeted at the definition of adverse and harmful effects. The lack of legislation worldwide is a direct result of the lack of technical and scientific support; when disputing the sale and consumption of these products, it is necessary to present data that support regulatory measures regarding clove cigarette. Understanding the damage caused by kretek is intrinsically linked to the analytical quantification of the cigarette, allowing an appropriated toxicological evaluation, supporting regulatory agencies around the world.

\section{References}

1. Ravenholt R T (1990) Tobacco's Global Death March. Population and Development Review 16(2): 213-240.

2. Reeve, Michael (2018) Smoking and Cigarette Consumption International Encyclopedia of the First World War p. 1-5.

3. Lum KL, Polansky JR, Jackler RK, Glantz SA (2008) Signed, sealed and delivered: "Big tobacco" in Hollywood, 1927-1951. Tobacco Control 17(5): 313- 323.

4. Song, AV, Ling PM, Neilands TB, Glantz SA (2007) Smoking in Movies and Increased Smoking Among Young Adults. American Journal of Preventive Medicine 33(5): 396-403.

5. (2017) WHO, World Health Organization. WHO Report on the global tobacco epidemic, 2017: Monitoring tobacco use and prevention policies. Geneva.

6. Hanusz M (2000) Kretek: The Culture and Heritage of Indonesia's Clove Cigarettes. Jakarta, Indonesia: Equinox Publishing pp. 203.

7. Polzin GM, Stanfill SB, Brown CR, Ashley DL, Watson CH (2007) Determination of eugenol, anethole, and coumarin in the mainstream cigarette smoke of Indonesian clove cigarettes. Food and Chemical Toxicology 45 (10): 1948-1953.

8. Malson JL, Lee EM, Murty R, Moolchan ET, Pickworth WB (2003) Clove cigarette smoking: biochemical, physiological, and subjective effects. Pharmacology, biochemistry, and behavior 74 (3): 739-745.

\section{ISSN: 2574-1241}

DOI: 10.26717/BJSTR.2019.18.003205

João Marcelo Astolfi Picanço. Biomed J Sci \& Tech Res

This work is licensed under Creative Commons Attribution 4.0 License

Submission Link: https://biomedres.us/submit-manuscript.php
9. Chaieb K, Hajlaoui H, Zmantar T, Kahla Nakbi AB, Rouabhia M, et al. (2007) The Chemical Composition and Biological Activity of Clove Essential Oil, Eugenia caryophyllata (Syzigium aromaticum L. Myrtaceae): A Short Review. Phytotherapy Research 21(6): 501-506.

10. LaVoie EJ, Adams JD, Reinhardt J, Rivenson A, Hoffmann D (1986) Toxicity studies on clove cigarette smoke and constituents of clove: determination of the LDs0 of eugenol by intratracheal instillation in rats and hamsters. Archives of Toxicology 59(2): 78-81.

11. T L Guidotti, L Laing, U B Prakash (1989) Clove Cigarettes: The Basis for Concern Regarding Health Effects. The Western Journal of Medicine 151(2): 220-228.

12. Roemer E, Dempsey R, Hirter J, Deger Evans A, Weber S, et al. (2014) Toxicological assessment of kretek cigarettes Part 6: The impact of ingredients added to kretek cigarettes on smoke chemistry and in vitro toxicity. Regulatory Toxicology and Pharmacology 70(S1): 66-80

13. van der Eijk Y, Lee JK, M Ling P (2019) How Menthol Is Key to the Tobacco Industry's Strategy of Recruiting and Retaining Young Smokers in Singapore. Journal of Adolescent Health 64(3): 347-354.

14. Huh J, Timberlake DS (2009) Do smokers of specialty and conventional cigarettes differ in their dependence on nicotine? Addictive Behaviors 34(2): 204-211.

15. (2009) House of Commons of Canada. Bill C-10 p. 57-58.

16. (2009) US Government. Public Law 111-31 p. 1-84.

17. Jarman H, Schmidt J, Rubin DB (2012) When trade law meets public health evidence: The World Trade Organization and clove cigarettes. Tobacco Control 21(6): 596-598.

18. (2014) Commission Européenne. Directive 2014/40/EU of the European Parliament and of the Council. Official Journal of the European Union 127: 1-38.

19. (2006) Western Australia Government. Tobacco Products Control Act. p. 1-80.

20. (2012) ANVISA, Agência Nacional de Vigilância Sanitária. Resolução Da Diretoria Colegiada - RDC No 14

21.(2013) MPF, Ministério Público Federal. Ação Direta de Inconstitucionalidade No 4874. p. 1- 33.

22. (2013) STF, Supremo Tribunal Federal. Medida Cautelar na Ação Direta de Inconstitucionalidade 4.874

23. (2018) STF, Supremo Tribunal Federal. Reclamação 32.787.

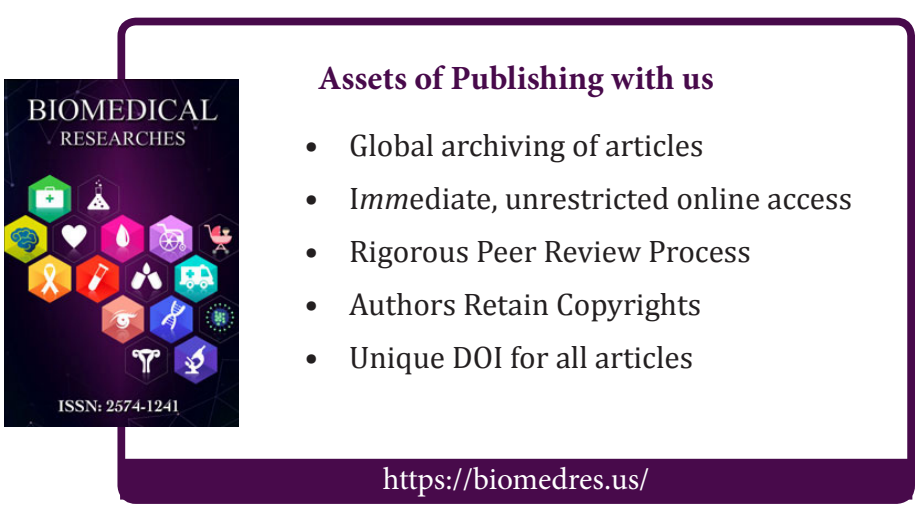

